\title{
Clinical Reactions and Serologic Changes After the Administration of Heterologous Antilymphocyte Globulin to Human Recipients of Renal Homografts
}

\author{
Noboru Kashiwagi, M.D., Charles O. Brantigan, B.A., Lawrence Brettschneider, M.D.,
} Carl G. Groth, M.D., and Thomas E. Starzl, m.D., Ph.D.

\section{Denver, Colorado}

\begin{abstract}
SUMMARY Clinical reactions and serologic changes after intramuscular administration of horse anti-human lymphocyte globulin (ALG) were studied in 53 human recipients of renal homografts. The ALG was used as an adjuvant immunosuppressive drug. In the usual case 47 injections were given over a 4-month period.
\end{abstract}

All patients had pain, tenderness, erythema, and swelling at the injection sites. Benign systemic side effects included fever in ali cases, hives in eight cases, rash in five, pruritus in five, arthralgia in three, and periorbital edema in one. Anaphylactic reactions occurred in 11 cases. These were easily treated, and there was complete recovery in every instance within $90 \mathrm{~min}$. In eight of these cases the ALG administration was discontinued. Subsequent injections were given in the other three.

Four of 11 patients tested had positive skin tests to ALG before therapy. Antibodies against sheep red blood cells developed during therapy in 39 of 40 patients; 10 reached titers as high as 1:128 to 1:512. Precipitin antibodies as measured with an electroimmunodiffusion technique developed in 36 of $\mathbf{4 0}$ patients. All three immunologic tests were of value in predicting the probability of an anaphylactic reaction, but the discrimination was imperfect.

Immunoelectrophoretic studies of sera from 13 patients showed antibodies to horse beta globulins in all cases, to alpha globulins in 9 cases, and to gamma globulins in only 1 . This finding indicates that a safer ALG could be made by removing the trace quantities of alpha and beta globulins from the immunologically more active gamma globulins.

URING THE LAST 14 MONTHS more than 2,000 intramuscular injections of horse anti-human lymphocyte globulin (ALG) have been given to 53 recipients of renal homografts. The potent immunosuppressive properties of antilymphocyte serum (ALS) or its globulin derivative have been known since the report of Waks-

Received September 21, 1967; revision accepted November 6, 1967.

From the Department of Surgery, University of Colorado School of Medicine and Denver Veterans Administration Hospital, Denver, Colo.

This work was supported by grants F05-TW-1154, AM 06283, AM 06344, HE 07735, AM 07772, AI 04152, FR 00051, and FR 00069, U. S. Public Health Service, Washington, D. C.

Requests for reprints should be addressed to Thomas Starzl, M.D., Veterans Administration Hospital, 1055 Clermont St., Denver, Colo. 80220. 
man, Arbouys, and Arnason (1). The ability of these agents to mitigate or even prevent rejection of skin homografts in inbred mice was first unequivocally demonstrated by Woodruff and Anderson (2). Since then, many investigators have noted these properties of both ALS and ALG, as has been recently summarized in accounts of our own canine studies with whole-organ kidney and liver transplantation $(3,4)$.

In most of the aforementioned studies the heterologous serum and globulin were evaluated as the sole therapy. It has also been shown that ALG has a synergistic action with other immunosuppressive agents $(3,5,6)$, and in the clinical trial to be described the immune globulin was used in combination with azathioprine and prednisone. Smaller doses of the latter drugs were sufficient to achieve adequate homograft protection $(3,4)$. The incidence of septic complications was reduced, and the 1-year survival of recipients of consanguineous homografts was increased to $95 \%$ (7).

These benefits have not been without corresponding penalties, as will be documented by an analysis of the clinical toxicity and the serologic changes in the first 53 patients who received treatment with ALG. In reviewing the findings attention will also be directed to possible ways in which ALG might be improved for future use.

\section{Methods \\ CASE MATERIAL}

Between June 1966 and August 1967 all patients who received renal homotransplantation at our institutions were treated with horse ALG, which was used as an adjuvant to therapy with azathioprine and prednisone. In 42 cases the homografts were obtained from familial donors; 37 of these recipients are still alive, with good renal function. Of six similar patients who received cadaveric homografts, four survive to date.

The ALG was ordinarily given daily for 5 days before operation, except in the cadaveric cases where pretreatment was omitted. After transplantation injections were given each day for 2 weeks, then every other day for 2 weeks, twice a week for 2 months, and once a week for a final month. A full course consisted of approximately 47 injections, but 2 patients received 79 injections each.

There were an additional five patients who received a similar course of ALG therapy from $3 \frac{1}{2}$ to 11 months after transplantation in an effort to reduce the doses of prednisone and azathioprine that were required to prevent an insidious progressive rejection. Two of these five patients are still alive.

The features of the ALG used in this study have been described elsewhere (8). It was prepared by ammonium sulfate precipitation of the serum of horses that had been immunized against human spleen, lymph node, and thymus lymphocytes. Approximately $90 \%$ of the protein was gamma G globulin. The rest was T-equine, beta, and alpha globulin. The total protein content varied from 4.6 to $10.8 \mathrm{~g} / 100$ $\mathrm{ml}$, and the leukoagglutinating titer varied between 1:4,000 and $1: 32,000$. The individual doses were 1 to $5 \mathrm{ml}$. During the period of daily injections the protein doses per week were 10 to $50 \mathrm{mg} / \mathrm{kg}$ body weight.

The way in which azathioprine and prednisone were used did not differ from that in previous cases (9), except that smaller doses of both were required to prevent rejection, as documented elsewhere $(3,4,7)$. In a few cases prednisone was given in the absence of rejection, usually because of rising titers of precipitins or hemagglutinins or both.

The courses of four patients in the group were of unusual interest since they received two series of protein injections. The initial injection schedules were for 5 days, 1 week, 1 month, and 4 months, respectively. The subsequent intervals were for $2,3,2$, and $1 \frac{1}{2}$ months. The second courses were for a full 4 months in all but the first patient, who died 7 days after globulin reinstitution. The death, which occurred 2 days after transplantation, was due to a surgical complication.

\section{MMUNOLOGL-XUDIES}

Skin Tests: Eleven patients received serial skin tests with intradermal injection of $0.1 \mathrm{ml}$ ALG. The presence of erythema and wheal formation was noted after $30 \mathrm{~min}$ and graded by the following scale: no reaction (same as saline control) $=-$; erythema only $= \pm$; ery thema and wheal less than $10 \mathrm{~mm}=+$; erythema and wheal more than $10 \mathrm{~mm}$ (including pseudopodia $)=++$.

Positive findings indicate the presence of 1 reagin. At $24 \mathrm{hr}$ edema, vesicles, petecniae, 
and necrosis were looked for. The latter signs would have indicated an Arthus reaction, although there is an overlap with delayed tuberculin-type reactions.

Frinagglutinin Titers: These were determined by a micro technique (10) in which patients' sera were tested against a $2 \%$ suspension of sheep red blood cells to determine the presence of Forssman-like antibodies (11).

Precipitin Titers: These were determined by the electroimmunodiffusion method of Merrill, Hartley, and Claman (12). Glass slides were coated with $1 \%$ Difco purified agar in veronal buffer (pH, 8.6; ionic strength, 0.05) to which $5 \mathrm{ml} / 100 \mathrm{ml}$ of normal horse serum were added. Seven wells, each $2 \mathrm{~mm}$ in diameter, were cut in the slide to accommodate the samples being analyzed. Electrophoresis was carried out for $60 \mathrm{~min}$ at $7.5 \mathrm{v} / \mathrm{cm}$ in veronal buffer $(\mathrm{pH}, 8.6$; ionic strength, 0.1$)$. The slides were then fixed and stained with amido black.

To create an arbitrary numerical scale, pooled sera of two patients with known sensitivity to horse protein were prepared in serial twofold dilutions and subjected to electroimmunodiffusion. A semilogarithmic plot of the length of the precipitating bands of these serially diluted sera produced a straight line which was used as a standard against which the serum being tested could be compared. The length of the band at 1:1 dilution of the pooled control sera was defined as 100 units. The method provided an extremely sensitive way of following serial changes in titer in the ALGtreated patients, but only as these related to the precipitin content in the standard sera.

It was not feasible to obtain accurate nitrogen weights of the precipitins in either the standard or the test sera, since the antibodies proved to be heterogenous. The precipitin titer of the undiluted standard serum, as measured by the ring method of twofold dilution of antigen (normal horse serum), was 1:5,120.

Further Characterization of Precipitin Response: These studies were done to determine if the human antibody response was directed against specific classes of horse immunoglobulins. The pooled serum from two patients known to have been sensitized to ALG was tested by placing it in wells cut from agar that contained $250 \mu \mathrm{g} / \mathrm{ml}$ of purified horse alpha, beta, or gamma globulins (Cohn's fractions IV III, and II, respectively.*

Immunoelectrophoresis was performed on the serum of 12 other globulin-treated patients, using a modification of Scheidegger's method

- Hyland Laboratories, Los Angeles, Calif.
(13). Slides were coated with $1 \%$ agar in veronal buffer ( $\mathrm{pH}, 8.6$; ionic strength, 0.05). Wells and troughs were cut. Normal horse serum was placed in the wells and electrophoresed at 7 $\mathrm{v} / \mathrm{cm}$ for $45 \mathrm{~min}$ in veronal buffer $(\mathrm{pH}, 8.6$; ionic strength, 0.1 ). The serum to be analyzed was placed in the trough and incubated for 24 to $72 \mathrm{hr}$. The slide was fixed and stained with amido black, and the nature of the antibody was identified by the localization of the precipitin band. To aid in the accurate delineation of the immunoglobulin classes, similar experiments were done using specific rabbit anti-horse serum * instead of human serum.

\section{Results}

\section{CLINICAL OBSERVATIONS}

Local Effects: Every patient had pain and tenderness at the site of injection, which was usually in the buttock. Although the discomfort varied from patient to patient, it was characteristically severe, especially with the first several and the last few injections. It would begin within 2 to $3 \mathrm{hr}$ and reach a peak within several hours; it often lasted for 4 to $24 \mathrm{hr}$. In many cases the pain was not confined to the gluteal region but involved the whole leg. Propoxyphene hydrochloride (Darvon ${ }^{\circledR}$ ) gave fair relief, though the local application of heat was more effective. A number of patients found that motion of the involved leg, either active or passive, gave relief. Only a few had pain severe enough to require narcotics.

Injections almost invariably caused local erythema and swelling. These findings were most noticeable as pain reached a peak but tended to persist longer. Occasionally, erythema and swelling involved the whole buttock and upper thigh. One patient had sunburn-like erythema on his left buttock after each shot which matured like sunburn and desquamated. Local itching was never severe but was noted by one third of the patients. Skin necrosis was not seen.

Two patients formed gluteal abscesses at or near sites of ALG injection. In one abscess, which contained Clostridium sapro- 
genes, the infection was believed to have been secondary to prior therapy with intramuscular antibiotics. In the other patient who was being treated with anticoagulants for thrombophlebitis there was hemorrhage in the needle tract. The resulting abscess was sterile. Both patients had uneventful healing after incision and drainage. A third patient developed pneumococcal cellulitis in the buttock and thigh which was easily controlled with penicillin therapy.

Systemic Effects: Virtually all the patients developed fever both during the preoperative period, when ALG was the only immunosuppressive agent being given, and later, when prednisone and azathioprine were also being administered. In most cases this was low-grade, but in some it spiked to 39 or $40 \mathrm{C}$, with a regular time relation to each injection. Many of these patients had chills. The more severe fevers had accompanying tachycardia. The only treatment given was aspirin.

Other benign reactions included hives (eight cases), rash (five cases), and generalized pruritus (five cases). These were effectively treated with antihistaminic agents. Three patients had arthralgia, and one experienced periorbital edema.

Eleven patients had anaphylactic reactions; in eight of these the ALG was immediately discontinued. In the other three, therapy was continued for more than a month and then was stopped either because of additional similar reactions or because the course of injections had been completed.

The anaphylactic reactions were absolutely characteristic. Within 1 to $30 \mathrm{~min}$ after injection the patients developed profound anxiety, followed by nausea and, sometimes, by an urge to defecate. Most complained of diffuse low-back pain and dyspnea.

The usual physical findings were hypotension and cyanosis of variable severity. The blood pressure falls were sometimes minor, but in others the recorded values were 40 to $60 \mathrm{~mm} \mathrm{Hg}$. At this time cyanosis with distention of the neck veins was always observed. Usually, the extent of desaturation seemed far greater than the discomfort exhibited by the patient; in one case an arterial oxygen saturation of $20 \%$ was recorded. In the usual case a temperature spike occurred, occasionally accompanied by chills.

Treatment was immediately instituted with $50 \mathrm{mg}$ intravenous prednisolone and nasal oxygen. Many patients also received $100 \mathrm{mg}$ diphenhydramine hydrochloride (Benadryl ${ }^{\circledR}$ ) intravenously. A liter of lactated Ringer's solution was given. Epinephrine was not required. All patients recovered in 5 to $90 \mathrm{~min}$. In no instance were there any demonstrable aftereffects.

A number of other side effects of ALG were looked for. Nine of the patients had thrombocytopenia $(<50,000)$ at some time in the postoperative course at a time when leukopenia was not present, but this could have been attributable to the azathioprine which was also being given. Nevertheless, a reduction in ALG in two patients with low platelet counts was followed by a prompt relative thrombocytosis. Some of the batches of ALG being used have been shown to have platelet-agglutinating properties (4).

There were no neurologic complications, peptic ulcers, myositis, abdominal pain, or pericardial and pleural effusions. The first eight consecutive patients had homograft biopsies after approximately 4 months of ALG therapy. As described elsewhere (4), there was no evidence of serum sickness or Masugi nephritis in any of the specimens.

None of the four patients who were rechallenged with ALG injections from $1 \frac{1}{2}$ to 3 months after an original course of therapy had serious systemic reactions.

\section{IMMUNOLOGIC STUDIES}

Skin Tests: Before the institution of ALG treatment 4 of 11 patients had positive tests at $30 \mathrm{~min}$, with wheal and 


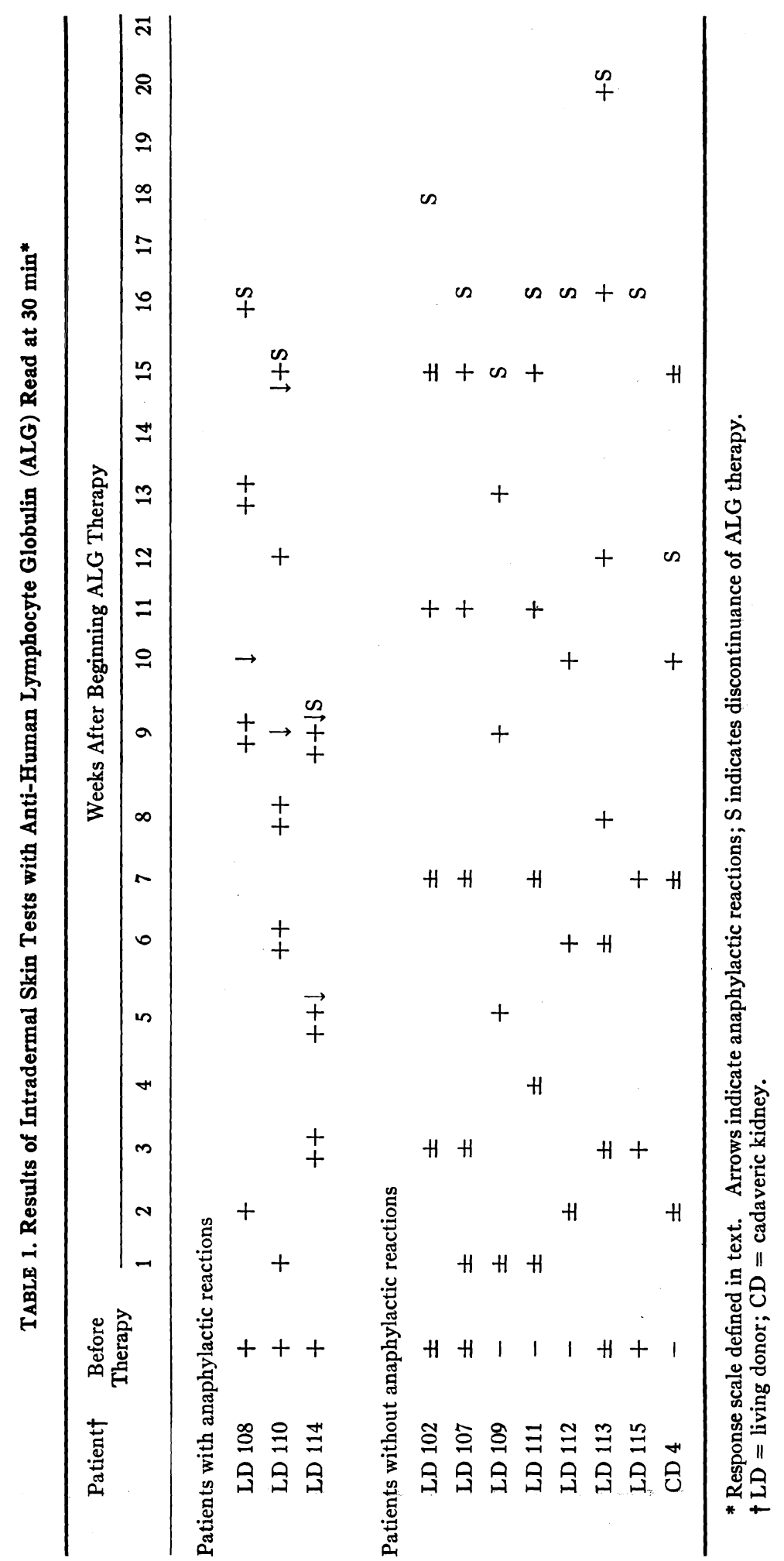




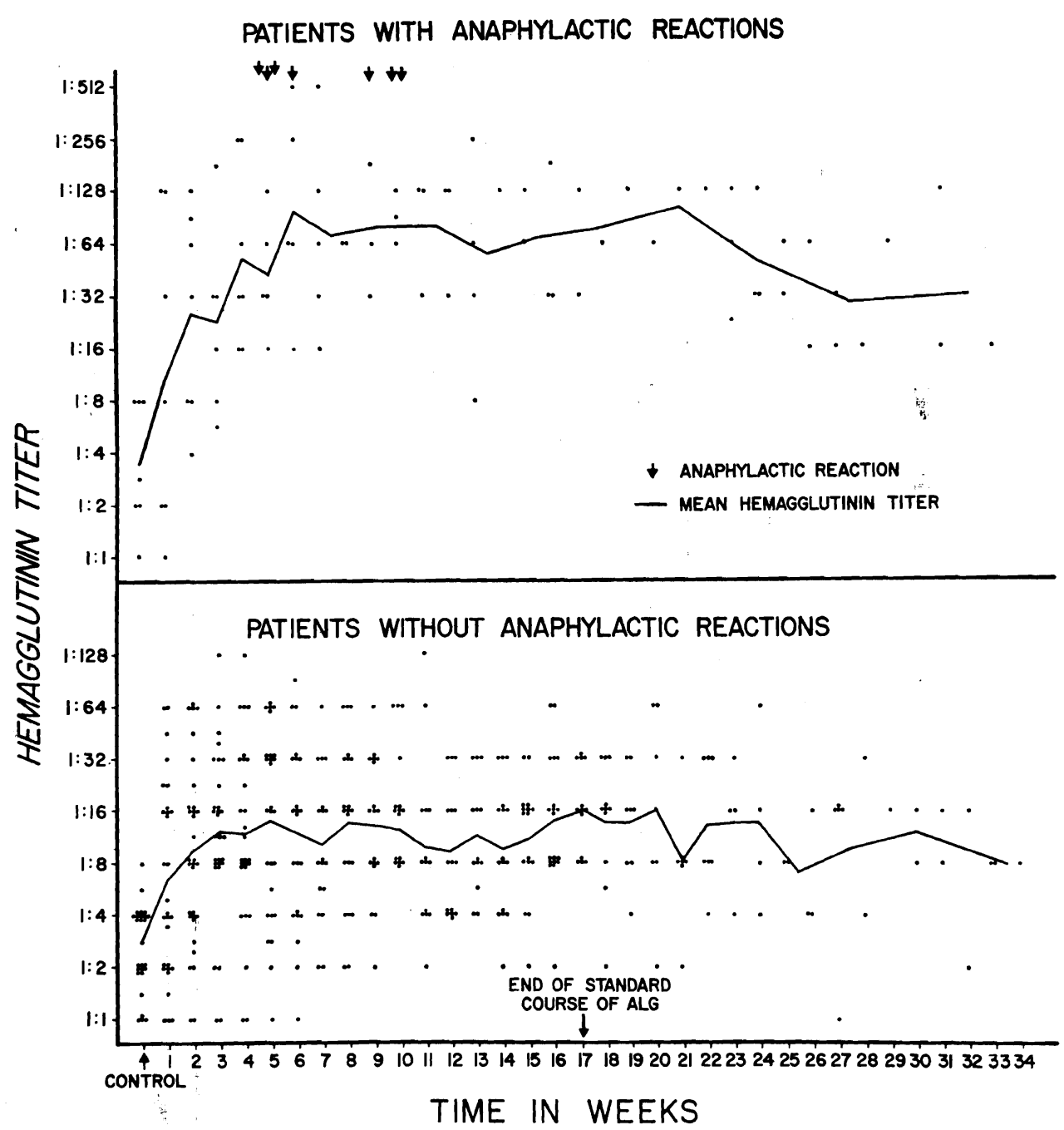

FIGURE 1. Hemagglutinin titers against sheep red blood cells in 40 patients receiving anti-human lymphocyte globulin $(A L G)$.

erythema. Three of these ultimately developed anaphylactic reactions after weeks or months of intramuscular therapy. In contrast, none of the other seven patients had this complication even though they also eventually developed positive skin tests (Table 1).

The skin test readings at $24 \mathrm{hr}$ roughly paralleled those at $30 \mathrm{~min}$. In addition, petechiae, vesicles, and necrosis were seen at $24 \mathrm{hr}$ in two patients who later had anaphylactic reactions. These patients also ultimately developed hives and arthralgia.
There were several others with negative pretherapy skin tests who also ultimately manifested the latter side effects after their intradermal reactions had become positive.

Hemagglutinin Titers: Antibodies against sheep red blood cells developed in 39 of 40 patients. The titers increased in rough parallel with those of the precipitins to be described below, but more sluggishly. In ten cases the hemagglutinin titers rose to $1: 128$ to $1: 512$. In seven of the ten there eventually was an anaphylactic reaction but usually some time after the peak 
titer level had been reached. Thus, the appearance of high levels of hemagglutinins was a warning of a possible anaphylactic reaction (Figure 1), but it did not predict when this would occur.
Precipitin Titers: Precipitin reactions were negative with electroimmunodiffusion in each of 40 patients before ALG injections. During therapy all except 4 had a rise in titer. The development of a high

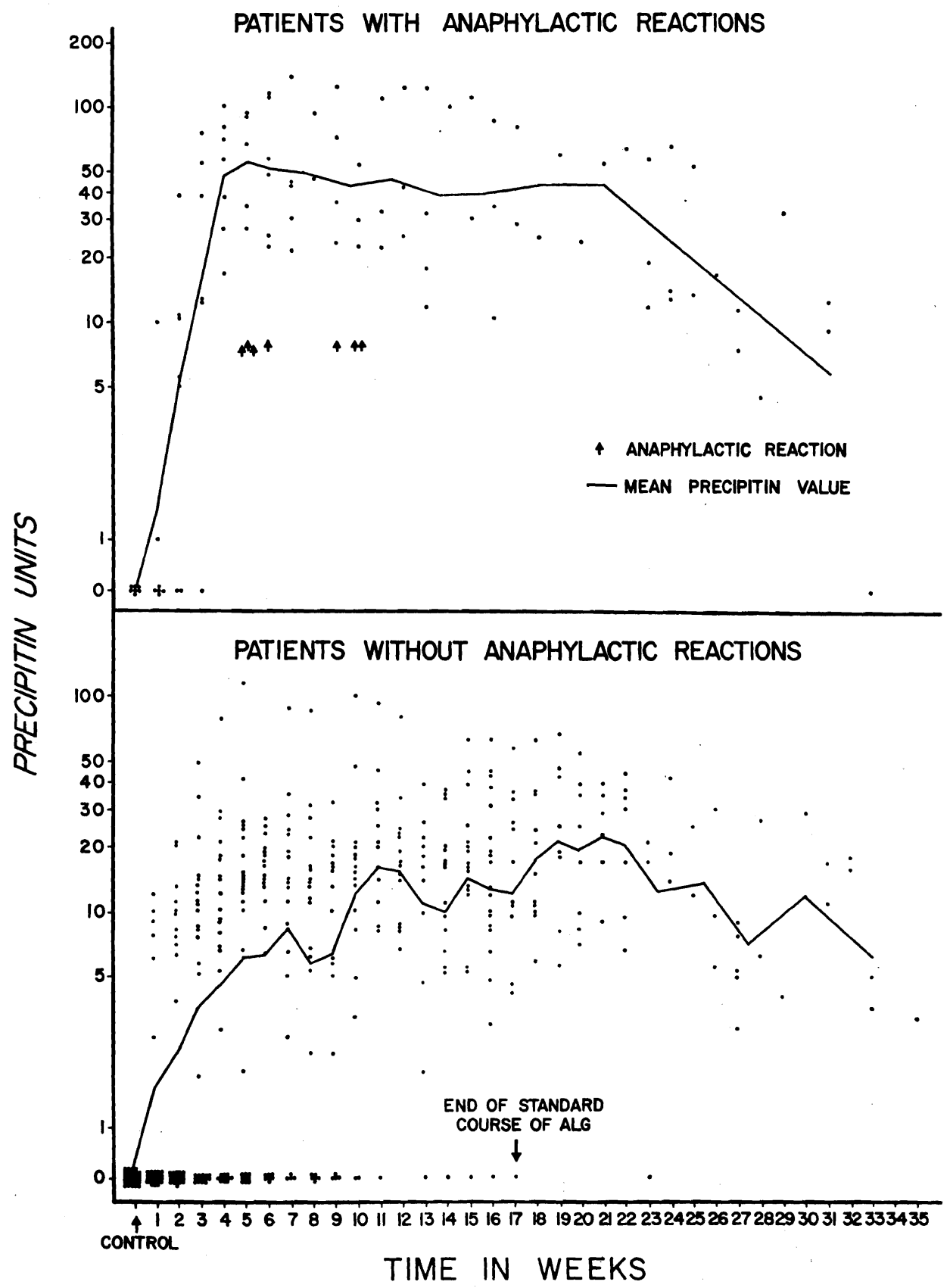

FIGURE 2. Precipitin titers in units (see text) in 40 patients receiving anti-human lymphocyte globulin $(A L G)$. 
titer correlated with development of anaphylactic reactions (Figure 2), but there was overlap. Of 6 patients who developed precipitin bands greater than 48 units, 5 had anaphylactic reactions. Among the other 34 whose titers were always less then 48 units only 2 exhibited such reactions. These 2 patients had a maximum of 34.7 and 32.7 units. There was no correlation of the precipitin levels with other side effects such as hives and arthralgia.

The rapidity of elevations in precipitin titers also seemed to be a significant prognostic sign. The patients who eventually had anaphylactic reactions tended to have detectable increases in precipitins at an early time, often within a few days or weeks after beginning therapy (Figure 2). In contrast, those who did not have this complication had more sluggish titer rises. In the majority of cases the precipitin titers began to subsequently decline even though the protein injections were continued and despite the fact that immunosuppression with prednisone and azathioprine was often being lightened.

The early use of prednisone blunted the precipitin response. Patients who received steroids from the time of operation onward generally had low and slowly rising titers (Figure 3), while those who had prednisone therapy delayed (Figure 4) or withheld altogether usually showed a rapid increase to high levels.

Three of the four patients who received a second course of ALG had falling precipitin titers when therapy was reinstituted; in the fourth, precipitating anti-

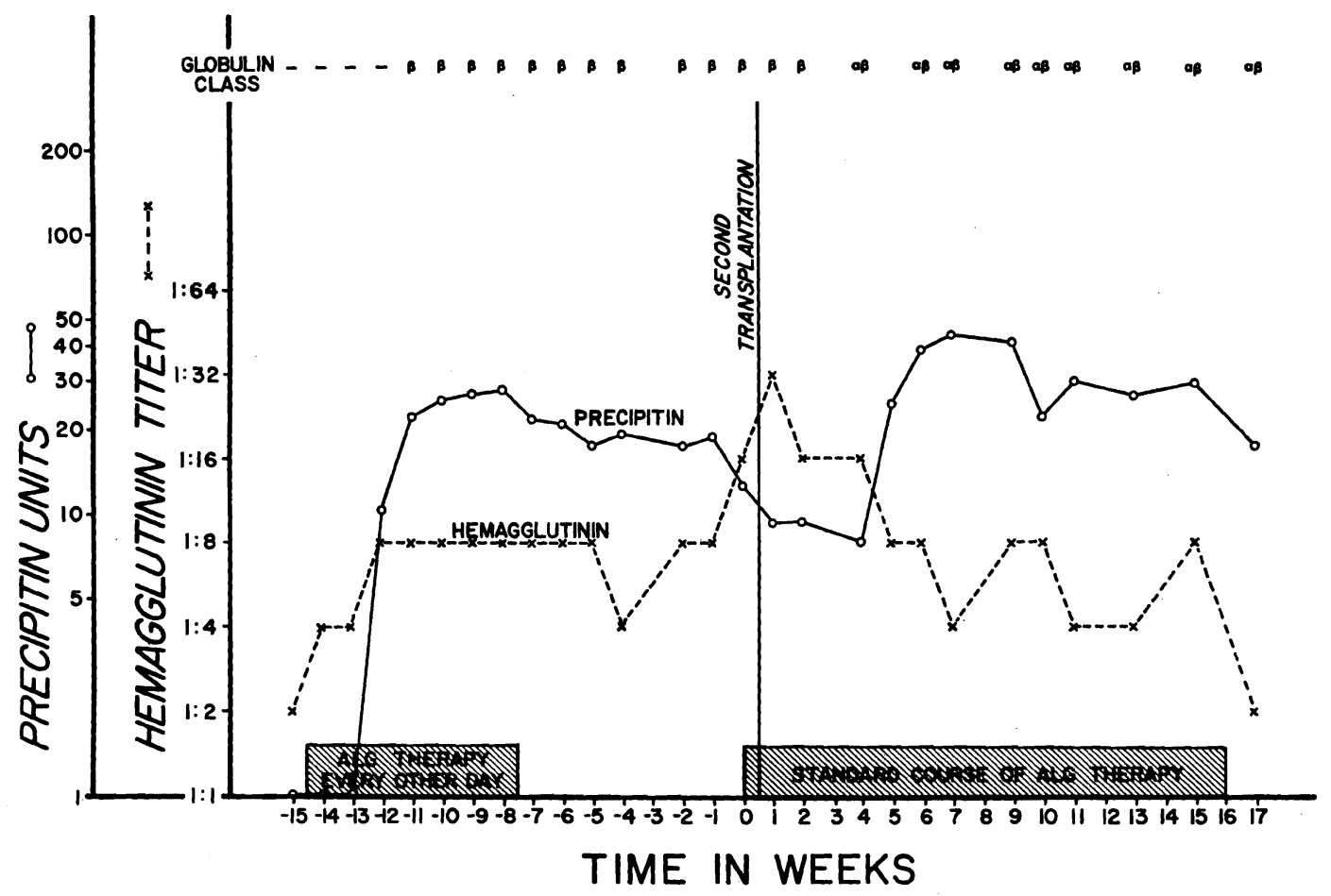

Figure 3. Immunologic data on a patient who received two courses of anti-human lymphocyte globulin $(A L G)$ therapy. The first was given in an attempt to control chronic rejection 5 months after a cadaveric transplant, and the second was given before and after retransplantation with a kidney from a related donor. Note that the hemagglutinin and precipitin responses were not accelerated with the second course. Prednisone was started immediately after the retransplantation. No anaphylactic reactions occurred. The Greek symbols indicate the globulin classes against which the precipitins were directed. 


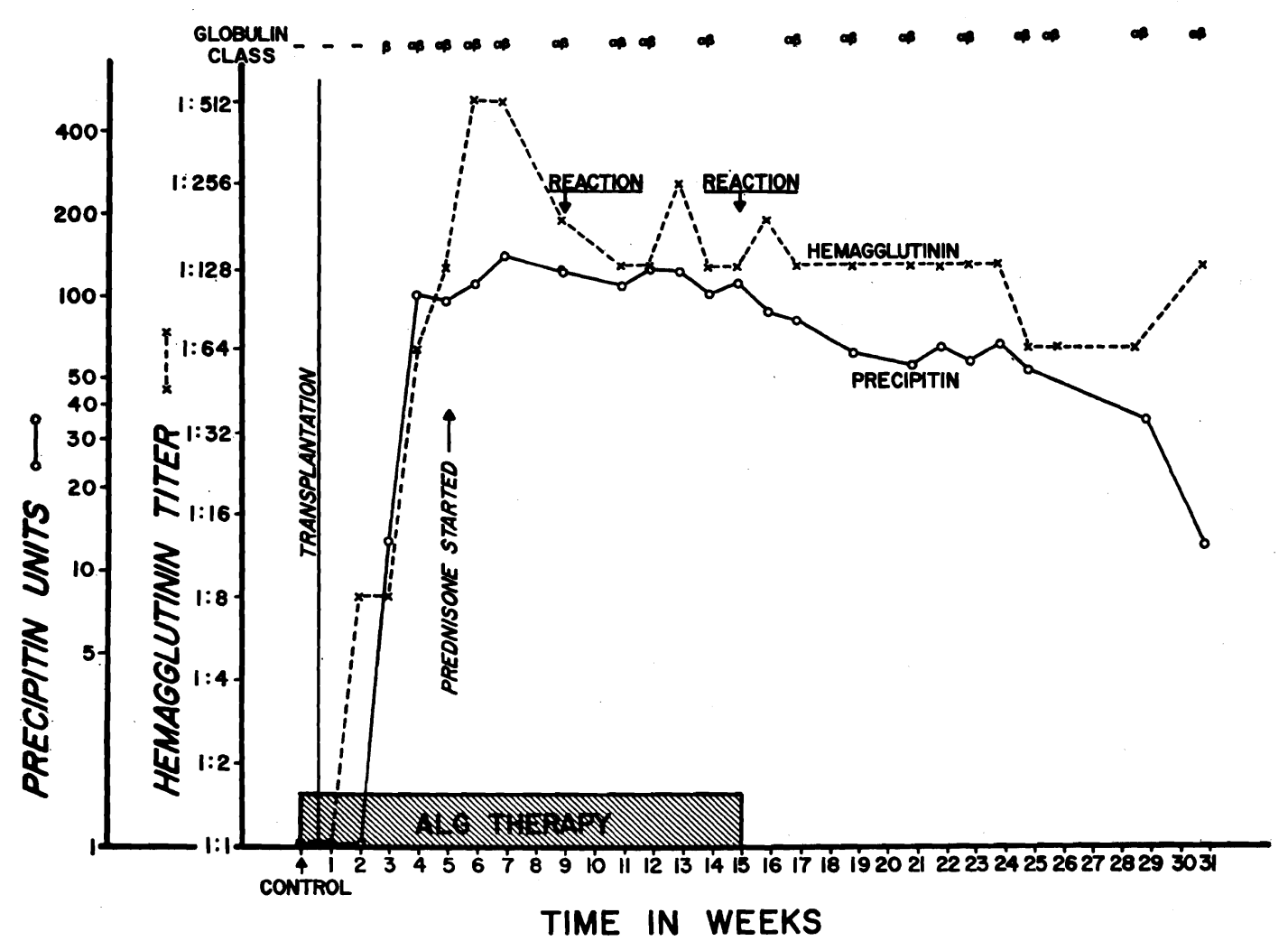

FIGURE 4. Immunologic data on a patient treated with anti-human lymphocyte globulin $(A L G)$ for 15 weeks posttransplantation. Prednisone was not started until the fifth postoperative week and then was started because of the high serologic titers rather than for rejection. The Greek symbols indicate the globulin classes against which the precipitins were directed.

bodies were not detectable during either course. With retreatment the precipitin bands in the first three patients rose to a maximum of 11,42 , and 45 units, respectively, but not at a more rapid rate than originally. The results were not correlated with changes in hemagglutinin titers since only one patient (Figure 3) had any secondary rise in the latter values.

Characterization of Precipitin Response: With electroimmunodiffusion the pooled serum from the two patients known to be sensitized to horse ALG showed a prominent band against horse beta globulin and a weak band against alpha globulin. There was only a trace of antibody against gamma globulin (Figure 5).

The studies with the alternative method of immunoelectrophoresis tended to sup- port these findings. All 13 patients studied had demonstrable antibodies to horse beta globulins at some time in their course, and 9 developed antibodies to alpha globulins. Anti-gamma antibodies were found in only one patient (Table 2).

\section{Discussion}

Although there has been a large number of recent reports of the ability of ALS and ALG to prevent homograft rejection in animals (14), there have been no accounts of the toxicity from the administration of these substances to man except for our own preliminary report (4) and those of Monaco, Wood, van der Werf, and Russell $(15,16)$.

An impressive clinical literature summarized by Kojis (17) and Arbesman (18) exists on the side effects of animal protein 


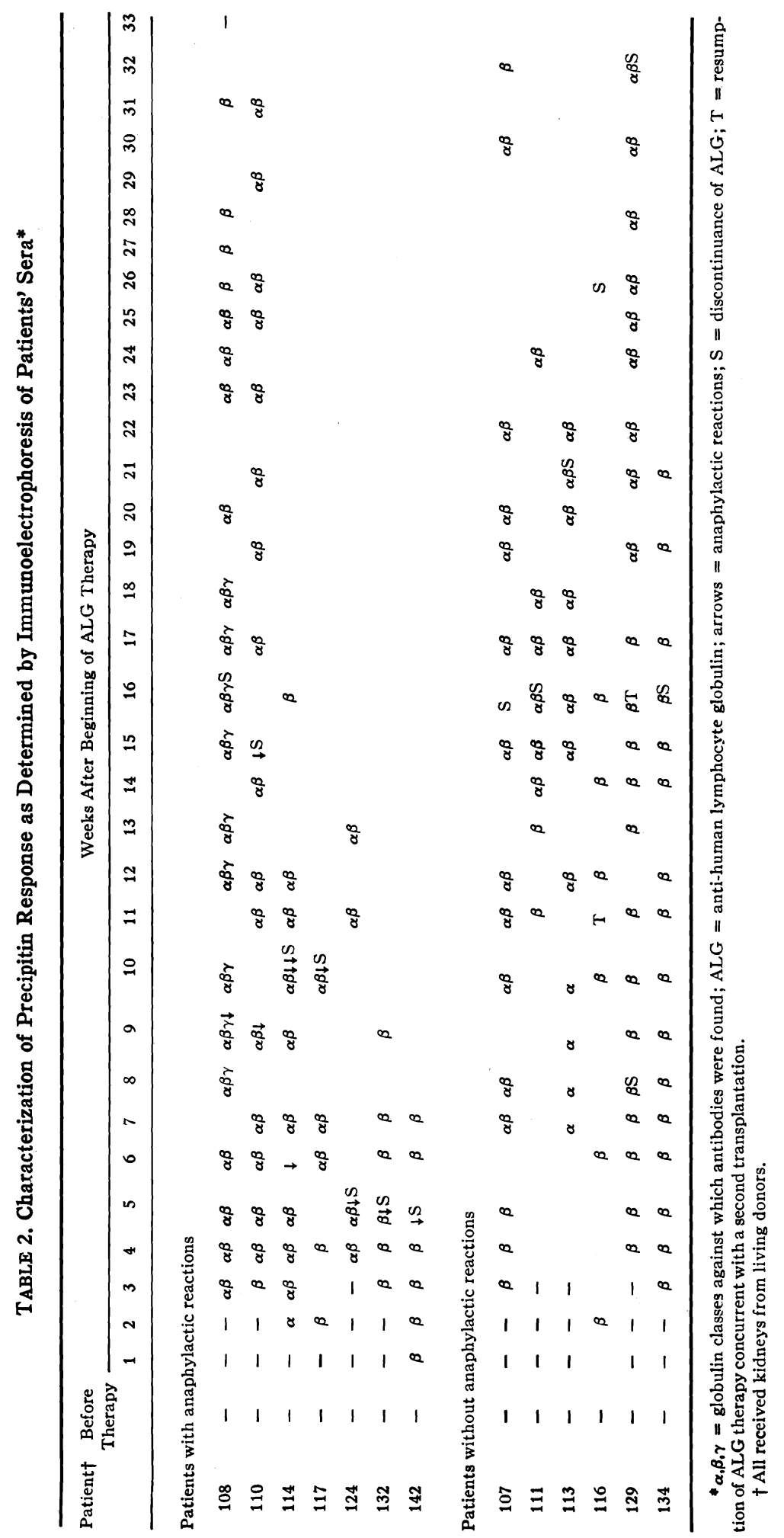


injections given as part of the treatment of tetanus, diphtheria, gas gangrene, pneumococcal pneumonitis, and other infections. However, it was hoped $(4,5,19,20)$ that the well-known dangers of foreign protein therapy would be less with ALS or ALG since their action might be expected to retard an antibody response by the treated subject; this has been referred to as a "self-antidotal" effect. The concomitant administration of other immunosuppressive agents such as azathioprine and prednisone could be expected to provide an additional margin of safety.

These expectations seem to have been at least partially fulfilled by the experiences herein reported, in which more than 2,000 individual intramuscular injections of ALG were given. There has not been an ALG-related mortality among the 53 consecutive patients who received a course of therapy that usually lasted for 4 months. Furthermore, there was no evidence in the homografts of the first 8 of these patients who received renal biopsies at the end of 4 months that they had developed either Masugi or serum sickness nephritis in their transplants (4). Nevertheless, a clear warning that the latter complication may occasionally occur was given in the report by Monaco, Wood, van der Werf, and Russell (15), who observed serum sickness nephritis in a normal volunteer who was being administered rabbit gamma $G$ globulin.

The more common undesirable effects of ALG administration were by no means inconsequential. These invariably included pain and swelling at the site of injection as well as elevations in temperature which were sometimes to high levels. Rashes, hives, itching, arthralgia, and periorbital edema were occasionally noted. Thus, at some time a significant number of patients developed one or more of the clinical manifestations of serum sickness as defined by Kojis (17). A possibility exists that thrombocytoperia may also have occasionally been caused by ALG.

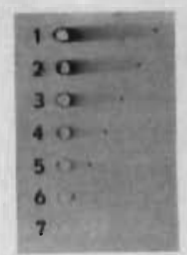

AGAR CONTAINING $5 \%$ HORSE SERUM

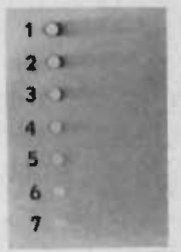

AGAR CONTAINING $250 \mu \mathrm{g} / \mathrm{ml}$ AGAR CONTAINING $250 \mu \mathrm{g} / \mathrm{ml}$ OF HORSE $P$ (COHN'S FR. III) OF HORSE $\gamma$ (COHN'S FR. II)

Ficure 5. Results with electroimmunodiffusion of pooled sera from two patients known to be sensitized to anti-human lymphocyte globulin when sera were tested against whole normal horse serum and several of its immunoglobulin fractions. Well 1 = patient scrum undiluted; well $2=1: 2$ dilution; well $3=1: 4$ dilution; well $4=1: 8$ dilution; well 5 $=1: 16$ dilution; well $6=1: 32$ dilution; well $7=$ 1:64 dilution.

None of the foregoing complications were life-threatening, and they were not considered indications for discontinuance of therapy. In contrast, the anaphylactic reactions that were seen in $21 \%$ of the patients led to a decision for immediate cessation of therapy in 8 of 11 cases despite the fact that more injections were given in the other 3 without serious consequences. The anaphylactic reactions were variable in severity, but in every instance they were rather easily treated and of short duration. With increased experience it became easier to view such reactions with less alarm than at the beginning. It was particularly interesting that none of the four patients who received a second course of ALG had clinically evident anaphylaxis.

The immunologic studies used to track the patient antibody responses against the foreign protein were of some value in predicting the possibility of an anaphylactic reaction-correlations that were similar to those in the classical studies of Longcope 
and Rackman (21) almost 50 years ago. Precipitin titers, hemagglutinin titers, and skin tests all had about the same degree of discrimination. However, neither a single test nor any combination was infallible. Moreover, it was possible to treat patients for several months before an anaphylactic reaction appeared despite clear evidence from the tests that such might eventually occur.

The immunosuppressive qualities of ALG are believed, as judged by several criteria (14), to reside in the gamma G globulin. This fact, as well as the demonstration that the principal precipitin response to ALG is to the small quantities of nonessential alpha and beta globulins that it contains, raises the possibility of having a safer but equally potent ALG, since isolation of pure gamma $G$ globulin is possible on a commercial basis.

\section{References}

1. Waksman, B. H., Arbouys, S., Arnason, B. G.: The use of specific "lymphocyte" antisera to inhibit hypersensitive reactions of the "delayed" type. J. Exp. Med. 114: 997, 1961.

2. WoodrufF, M. F. A., ANDERson, N. F.: Effect of lymphocyte depletion by thoracic duct fistula and administration of antilymphocytic serum on the survival of skin homografts in rats. Nature (London) 200: 702, 1963.

3. Starzl, T. E., Marchioro, T. L., Porter, K. A., Iwasaki, Y., Cerillli, G. J.: The use of heterologous antilymphoid agents in canine renal and liver homotransplantation, and in human renal homotransplantation. Surg. Gynec. Obstet. 124: 301, 1967.

4. Starzl, T. E., Porter, K. A., Iwasaki, Y., Marchioro, T. L., Kashiwagi, N.: The use of heterologous antilymphocyte globulin in human renal homotransplantation, in Antilymphocytic Serum, edited by Wolstenholme, G. E. W., O'ConnoR, M. J. \& A. Churchill Ltd., London, 1967, pp. 4-34.

5. LeVEy, R. H., Medawar, P. B.: Nature and mode of action of antilymphocyte antiserum. Proc. Nat. Acad. USA 56: 1130, 1966.

6. HoeHn, R., Simmons, R. L.: Immunosuppressive drugs combined with heterologous anti-lym. phocyte serum: a clinical regimer. for homograft prolongation. Surg. Forum. 17: 251, 1966.
7. Starzl, T. E., Groth, C. G., Terasaki, P. I., Putnam, C. W., Brettschneider, L., MarCHIORO, T. L.: Heterologous antilymphocyte globulin, histocompatibility matching, and human renal homotransplantation. Surg. Gynec. Obstet. In press.

8. Iwasaki, Y., Porter, K. A., Amend, J. R., MARchioro, T. L., Zühlke, V., Starzl, T. E.: The preparation and testing of horse antidog and antihuman antilymphoid plasma or serum and its protein fractions. Surg. Gynec. Obstet. 124: 1, 1967.

9. StARzL, T. E.: Experience in Renal Transplantation. W. B. Saunders Co., Philadelphia, 1964.

10. Sever, J. L.: Application of a microtechnique to viral serological investigations. J. Immun. 88: 320, 1962.

11. Davidsonn, I.: Heterophile antibodies in serum sickness. J. Immun. 16: 259, 1929.

12. Merrill, D., Hartley, T. F., Claman, H. N.: Electroimmunodiffusion (EID): a simple, rapid method for quantitation of immunoglobulins in dilute biological fluids. J. Lab. Clin. Med. 69: 151, 1967.

13. Scheidegger, J. J.: Une micro-methode de l'immuno-electrophorese. Int. Arch. Allerg. 7: 103,1955 .

14. Wolstenholme, G. E. W., O'Connor, M. (editors): Antilymphocytic Serum. J. \& A Churchill Ltd., London, 1967.

15. Monaco, A. P., Wood, M. L., VAN DER Werf, B. A., Russell, P. S.: Effect of antilymphocyte serum in mice, dogs and man, in Antilymphocytic Serum, edited by Wolstenholme, G. E. W., O'Connor, M. J. \& A. Churchill Ltd., London, 1967, pp. 111-134.

16. Monaco, A. P., Wood, M. L., Russell, P. S.: Some effects of purified heterologous antihuman lymphocyte serum in man. Trans. plantation 5: 1106, 1967.

17. KoJis, F. G.: Serum sickness and anaphylaxis. Amer. J. Dis. Child. 64: 93, 313, 1942.

18. Arbesman, C. E.: Clinical anaphylaxis and serum sickness, in Immunological Diseases, edited by Samter, M. Little, Brown and Co., Boston, 1965, pp. 654-662.

19. SACKs, J. H., Filippone, D. R., Hume, D. M.: Studies of immune destruction of lymphoid tissue. I. Lymphocytotoxic effect of rabbitanti-rat-lymphocyte antiserum. Transplantation 2: 60, 1964.

20. Gray, J. G., Monaco, A. P., Wood, M. L. Russell, P. S.: Studies on heterologous antilymphocyte serum in mice. I. In vitro and in vivo properties. J. Immun. 96: 217, 1966.

21. Longcope, W. T., RACKMAN, F. M.: The relation of circulating antibodies to serum dis. ease. J. Exp. Med. 27: 341, 1918. 